\title{
PENGEMBANGAN SISTEM INFORMASI TERPADU PAUD STUDI KASUS PAUD ASI (AURA SUKMA INSANI) SINGARAJA
}

\author{
K. D. Y. Pratama1), I M. A. Wirawan²), I G. M. Darmawiguna ${ }^{3)}$ \\ ${ }^{1}$ Fakultas Teknik dan Kejuruan, Universitas Pendidikan Ganesha \\ 2 Fakultas Teknik dan Kejuruan, Universitas Pendidikan Ganesha \\ ${ }^{3}$ Fakultas Teknik dan Kejuruan, Universitas Pendidikan Ganesha \\ Email: dwindayudha@gmail.com, imade.aguswirawan@undiksha.ac.id, mahendra.darmawiguna@undiksha.ac.id
}

\begin{abstract}
Abstrak
Pendidikan merupakan usaha sadar yang dilakukan untuk meningkatkan kualitas masyarakat. Pemerintah melalui pendidikan pada usia dini memiliki visi untuk meningkatkan kualitas masyarakat. Meningkatnya kualitas masyarakat ditentutan oleh meningkatnya kualitas pendidikan, semakin baik pendidikan yang diberikan maka semakin baik keluaran yang dihasilkan. Upaya untuk meningkatkan kualitas pendidikan salah satunya dengan mengembangkan pengelolaan dalam lembaga pendidikan, pengelolaan yang dimaksud adalah pengelolaan administrasi. Salah satu upaya untuk mengembangkan pengelolaan ini dilakukan dengan mengembangkan sebuah sistem yang dapat digunakan untuk meningkatkan kualitas dan efektifitas pengelolaan dalam bidang administrasi. Tujuan dari peneitian ini adalah untuk menghasilkan sebuah sistem yang dapat mengakomodir seluruh keperluan administrasi yang dilakukan di lembaga pendidikan paud dalam kasus ini menggunakan studi kasus pada paud aura sukma insani singaraja. Metode penelitian yang digunakan adalah penelitian pengembangan dengan model waterfall. Sistem informasi dikembangkan dengan framework Laravel dan Android Studio. Sistem dapat berjalan online maupun offline sesuai dengan kebutuhan dari lembaga pendidikan.. Hasil penelitian ini berupa sistem informasi terpadu yang dapat diakses dengan komputer pada server dan smartphone android pada client. Berdasarkan hasil pengujian, sistem informasi bekerja dengan baik. Sistem dinilai mampu untuk membantu masalah adminisrasi dengan presentasi nilai yaiitu $84,67 \%$. Sistem mendapat respon yang positif dari pengguna.
\end{abstract}

Kata kunci: Sistem Informasi, Android, Client Server, Pendidikan, Akademik

\begin{abstract}
Education is a conscious effort carried out to improve the quality of society. The government through education at an early age has a vision to improve the quality of society. Increasing the quality of society is determined by the increasing quality of education, better the education provided, better the output produced. One of the efforts to improve the quality of education is by developing management in educational institutions, the management in question is administrative management. One effort to develop this management is done by developing a system that can be used to improve the quality and effectiveness of management in the administrative field. The purpose of this research is to produce a system that can accommodate all administrative requirements carried out at the auditing institution in this case using case studies at aura sukma insani singaraja. The research method used is development research with the waterfall model. Systems are developed with the Laravel Framework and Android Studio. The system can run online or offline according to the needs of educational institutions. The results of this study are integrated information systems that can be accessed with computers on android servers and smartphones on the client. Based on the results of testing, the information system works well. The system is considered capable of helping administration problems with presentation values which are $84.67 \%$. The system received a positive response from users.
\end{abstract}

Keywords : Information System, Android, Client Server, Education, Academic 


\section{PENDAHULUAN}

Pendidikan memiliki banyak peranan penting dalam perkembangan hidup manusia. Salah satu peran penting pendidikan adalah menciptakan masyarakat yang cerdas, terbuka dan demokratis. Pendidikan sudah merupakan menjadi kebutuhan bagi setiap individu. Oleh karena itu pembaharuan pendidikan harus dilakukan untuk meningkatkan kualitas pendidikan [1]

Pendidikan adalah usaha sadar dan terencana untuk mewujudkan suasana belajar dan proses pembelajaran agar peserta didik secara aktif mengembangkan potensi dirinya untuk memiliki kekuatan spiritual keagamaan, pengendalian diri, kepribadian, kecerdasan, ahlak mulia, serta keterampilan yang diperlukan dirinya, masyarakat, bangsa dan negara. Untuk mengembangkan potensi peserta didik secara optimal, maka peserta didik harus bisa mengelola dirinya dengan baik [2]. Salah satu upaya untuk mengembangkan potensi peserta didik dengan menggiatkan pendidikan sedini mungkin. SISDIKNAS pasal 13 sampai 15 menyebutkan bahwa pendidikan di Indonesia dibagi menjadi jalur, jenjang, dan jenis pendidikan. Disisi lain terdapat juga penyelenggaraan pendidikan yang dapat membentuk karakteristik manusia melalui pendidikan anak usia dini.

Pendidikan Anak Usia Dini Aura Sukma Insani merupakan salah satu lembaga pendidikan yang bergerak pada pendidikan anak usia dini. Pendidikan yang dilaksanakan pada PAUD ASI bertolak ukur pada Peraturan Menteri Republik Indonesia No. 58 Tahun 2009 mengenai Standar Pendidikan Anak Usia Dini menjelaskan bahwa standar karakteristik penyelenggaraan PAUD terdiri dari empat kelompok yaitu: (1) Standar tingkat pencapaian perkembangan; (2) Standar pendidik dan tenaga kependidikan; (3) Standar isi, proses, dan penilaian; dan (4) Standar sarana dan prasarana, pengelolaan, dan pembiayaan. Salah satu komponen yang dinilai perlu diberikan pembaharuan adalah komponen standar penilaian dan pengelolaan. Standar penilaian merupakan proses pengumpulan dan pengolahan informasi untuk menentukan tingkat pencapaian perkembangan anak. Kemudian Standar pengelolaan merupakan proses untuk menjamin terpenuhnya hak dan kebutuhan anak, serta kesinambungan pelaksanaan pendidikan anak usia dini. Implementasi kedua standar penilaian dan pengelolaan membutuhkan ketelitian dan ketepatan, agar dapat menghasilkan output yang sesuai dengan keinginan.

Meningkatnya kualitas pendidikan pada sebuah lembaga pendidikan ditinjau dari beberapa faktor, seperti kurikulum yang digunakan, profesionalisme tenaga pengajar, pengelolaan administrasi yang baik [2]. Dari beberapa obseravasi yang dilakukan terdapat beberapa lembaga PAUD masih menggunakan metode konvensional dalam pengerjaan pengelolaan administrasi siswa dan guru sehingga rentan terjadi kesalahan dan menyita banyak waktu, sehingga dapat menyebabkan kesulitan dalam mengatur administrasi. Salah satu orang tua murid menyayangkan menurunnya kualitas dalam pelayanan kepada orang tua dalam pengelolaan administrasi yang dirasa membutuhkan waktu yang cukup lama dalam proses pengelolaanya.

Berikut peneliti rangkum hasil dari wawancara yang dilakukan dari beberapa penyelengara pendidikan anak usia dini di daerah Singaraja salah satunya adalah PAUD ASI pada tanggal 22 februari 2016, dapat dipaparkan beberapa kendala yaitu: 1. Administrasi yang dilakukan oleh pihak penyelenggara pendidikan anak usia dini membutuhkan waktu yang cukup lama yang disebabkan teknis atau cara masih menggunakan metode konvensional, sehingga mengakibatkan beberapa kasus yang terjadi data yang tercecer dan hilang. 2. Penyelenggara pendidikan anak usia dini ingin memberikan informasi terkait laporan harian atau laporan bulanan mengenai peserta didik secara cepat dan mudah agar dapat dipantau kapanpun dan dimanapun. 3. Orang tua ingin mendapatkan kenyamanan dari segi efektifitas waktu dan tempat dalam melaksanakan proses administrasi.

Berdasarkan permasalahan tersebut, maka perlu untuk dicarikan solusi dengan pemanfaatan teknologi berupa penerapan sistem informasi terpadu. Penerapan sistem informasi pada sebuah lembaga pendidikan akan berdampak pada efektivitas dan efisiensi dalam proses kerja yang dilakukan seperti pengolahan, pendataan, dan penyajian pada lembaga pendidikan [4]. Sistem Informasi (Information System) merupakan kombinasi teratur dari orang-orang, perangkat keras (hardware), perangkat lunak (software), jaringan komunikasi, dan sumber daya data yang dikumpulkan, mengubah, dan menyebarkan informasi dalam sebuah organisasi [5].

Seiring perkembangan teknologi yang sangat pesat berdampak pada bagaimana setiap orang berkomunikasi. Adapun contoh perangkat teknologi tersebut adalah telepon, telepon merupakan pesawat dengan listrik dan kawat, untuk bercakap-cakap antara dua orang yang berjauhan tempatnya; pesawat [11]. Sampai saat ini telepon terus berevolusi. Salah satu evolusi telepon adalah lahirnya handphone, handphone merupakan salah satu perangkat bergerak (mobile device) yang tidak pernah lepas dari kehidupan manusia, di mana saat ini terdapat istilah telepon pintar (smartphone). Smartphone adalah telepon yang internet-enabled yang biasanya menyediakan fungsi Personal 
Digital Assistant (PDA), seperti fungsi kalender, buku agenda, buku alamat, kalkulator, dan catatan [12]. Salah satu parameter sebuah telepon disebut telepon pintar adalah sistem operasi yang digunakan, sistem operasi adalah program-program komputer yang mengendalikan sumber daya piranti keras dan piranti lunak komputer kita.

Adapun proses yang mampu dilakukan sistem yang dirancang meliputi proses pendataan siswa baik data biodata, informasi perkembangan, serta data nilai dari masing-masing siswa. Kemudian selaian pendataan, sistem akan melayani laporan untuk proses administrasi pada lembaga pendidikan, baik berupa laporan akhir, laporan surat, laporan-laporan lain yang terintegrasi dengan peroses administrasi pada lembaga tersebut.

Berdasarkan permasalahan yang dipaparkan pada penjelasan tersebut, maka dapat disimpulkan bahwa sistem informasi terpadu untuk penyelenggara pendidikan anak usia dini sangat diperlukan untuk menangulangi permasalahan tersebut dan meningkatkan kualitas dari informasi yang ada. Sistem Informasi akan berperan denggan baik menangani administrasi secara teratur, terstruktur dan meminimalisir anggaran. Terpadu dalam hal ini merupakan sistem lain yang terbangung dalam sistem informasi yang akan ditambahkan sesuai dengan kebutuhan dari pihak penyelanggara pendidikan anak usia dini.

Tabel 1. Rincian Analisis Masalah Sistem Informasi Terpadu ASI

\begin{tabular}{lllll} 
No & \multicolumn{2}{c}{ Cause-and-effect analysis } & \multicolumn{2}{c}{ System improvement objectives } \\
& Masalah & Akibat & Target Sistem & Batasan Sistem \\
\hline $\mathbf{1}$ & Sulit dalam & Memerlukan waktu & Sistem akan & Kegiatan akademik yang \\
mendapatkan & yang lama untuk & menyediakan & dapat diakses meliputi data \\
& laporan data & mengetahui data & laporan tentang & siswa, data nilai, \\
siswa maupun & untuk pembuatan & data siswa dan & perkembangan siswa. \\
perkembangan & laporan akhir & perkembangan & \\
siswa & maupaun & siswa untuk & \\
& & mingguan & kegiatan akademik. & \\
$\mathbf{2}$ & Tidak ada kontrol & Orang tua siswa & Sistem dapat & Informasi yang dihasilkan \\
& orang tua siswa & kurang & menyediakan & meliputi perkembangan \\
& mendapatkan & informasi & siswa dan pengumuan \\
& informasi & perkembangan & kegiatan disekolah \\
& mengenai & siswa & \\
& perkembangan & & \\
& siswa & & \\
& & & \\
& & &
\end{tabular}

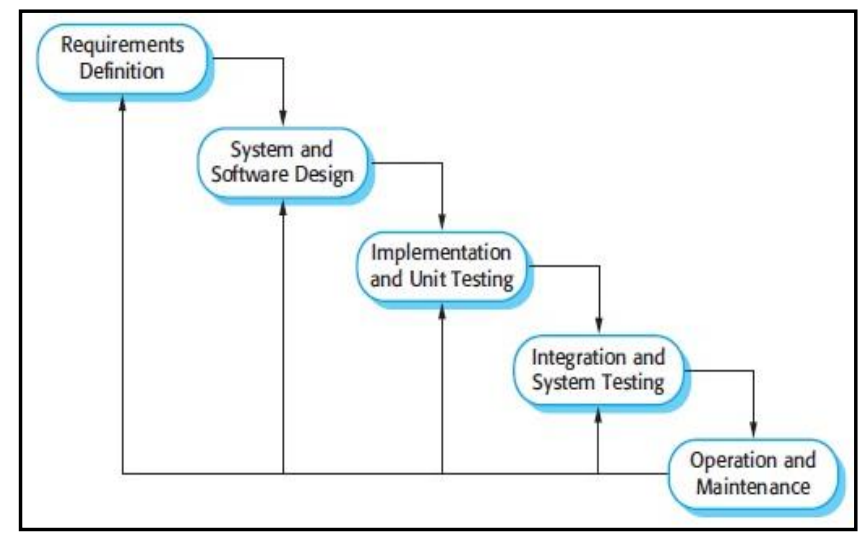

Gambar 1. Tahapan Model Waterfall Sistem Informasi Terpadu

Berdasarkan dari pemikiran ini penulis memandang permasalahan dapat diatasi dengan mengembangkan: Pengembangan Sistem Informasi Terpadu Pendidikan Anak Usia Dini Studi Kasus Pendidikan Anak Usia Dini ASI (Aura Sukma Insani) Singaraja. 


\section{METODE}

Pengembangan Sistem Informasi Terpadu untuk lembaga pendidikan anak usia dini menggunkan proses SDLC (System Development Life Cycle) yaitu dengan model waterfall, model waterfall merupakan model yang bersifat sistematis dan berurutan. menggunkan proses SDLC (System Development Life Cycle) yaitu dengan model waterfall, model waterfall merupakan model yang bersifat sistematis dan berurutan. Model waterfall merupakan model yang dikembangkan untuk pengembangan perangkat lunak secara sistematis dari satu tahap ke tahap yang lainnya seperti air terjun. Model ini mengusulkan pendekatan kepada pengembang perangkat lunak yang sistematika dan sekuensial yang dimulai dari sistem pada seluruh analisis, desain, kode, pengujian, dan pemeliharaan Model waterfall juga dikatakan model pengembangan yang bersifat linier dari tahap awal pengembangan sistem yaitu tahap perencanaan sampai tahap akhir pengembangan sistem yaitu tahap pemeliharaan. Tahapan berikutnya tidak akan dilaksanakan sebelum tahapan sebelumnya selesai dilaksanakan dan tidak bisa kembali atau mengulang ke tahap sebelumnya [3] Tahapan yang pertama adalah (A) Analisis Masalah dan Usulan Solusi Berdasarkan analisis masalah di tabel 1 atas maka solusi yang dapat diusulkan adalah pengembangan perangkat lunak Sistem Informasi Terpadu Pendidikan Anak Usia Dini ASI Singaraja. Perangkat lunak ini diharapkan mampu menangani permasalahan yang menjadi kelemahan di atas dan membantu efektifitas kinerja didalam Lembaga pendidikan. Dilanjutkan dengan (B) Analisis Perangkat Lunak yang dibagi menjadi : (1) Kebutuhan Perangkat lunak. Berdasarkan analisis terhadap pengembangan sistem, adapun beberapa kebutuhan yang dirancang dalam mengembangkan Sistem Informasi Terpadu Pendidikan Anak Usia Dini Aura Sukma Insani antara lain, melakukan proses login, pengelolaan data sekolah, pengelolaan data siswa, pengelolaan data nilai siswa, pengelolaan data perkembangan siswa, pengelolaan data guru, pengelolaan data surat, pengelolaan data kalender. Kebutuhan non-fungsional perangkat lunak antara lain, perangkat lunak ini memiliki antarmuka bersifat friendly mudah digunakan dan mudah diperasikan. Sistem dilengkapi dengan hak ases pengguna yang dibagi menjadi admin, guru dan orang tua. Sistem dirancang untuk dapat digunakan online agar dapat memberikan informasi secara realtime. (2) Tujuan perangkat lunak Adapun tujuan penelitian ini adalah membantu Lembaga Pendidikan Pendidikan Anak Usia Dini ASI Singaraja dalam melakukan administrasi agar lebih efektif dan efisien. Secara rinci tujuan yang ingin dicapai adalah sebagai berikut: (a) Membantu pengguna mengelola informasi terkait Lembaga Pendidikan (b) Membantu pengguna mengelola data informasi siswa. (c) Membantu pengguna mengelola data informasi guru. (d) Membantu pengguna mengelola data informasi surat. (e) Membantu pengguna mengelola data informasi kalender. (3) Masukan dan keluaran. Masukan pada perangkat lunak Sistem Informasi Terpadu Pendidikan Anak Usia Dini ASI Singaraja yaitu, data login, data informasi sekolah, data siswa, data nilai siswa, data perkembangan siswa, data guru, data surat dan data kalender. Keluaran dari perangkat lunak Sistem Informasi Terpadu Pendidikan Anak Usia Dini ASI Singaraja, yaitu hak akses, informasi data sekolah, informasi data siswa, informasi nilai siswa, informasi perkembangan siswa, informasi guru, informasi surat dan informasi kalender. (4) Model Fungsional Model fungsional perangkat lunak digunakan untuk menjelaskan bagaiaman gambaran umum dari perangkat lunak yang akan dikembangkan. Gambaran umum yang dibuat divisualisasikan dalam bentuk gambar ataupun diagram agar dapat dimengerti oleh pihak lain. Salah satu design sistem yang digunakan oleh berbagai kalangan adalah UML (Unified Modelling Language).

Tabel 2. Definisi Aktor Sistem Informasi Terpadu ASI

\begin{tabular}{|c|c|c|}
\hline No. & Nama Aktor & Deskripsi \\
\hline 1 & Admin & $\begin{array}{l}\text { Admin merupakan user yang memiliki hak akses untuk dapat } \\
\text { mengakases secara penuh kebutuhan perangkat lunak }\end{array}$ \\
\hline 2 & Guru & $\begin{array}{l}\text { Guru merupakan user yang diberikan kepada semua pengajar } \\
\text { untuk dapat mengakses semua keperluan terkait administrasi } \\
\text { pendidikan }\end{array}$ \\
\hline 3 & Orang Tua & $\begin{array}{l}\text { Orang Tua merupakan user yang diberikan kepada orang tua } \\
\text { peserta didik agar dapat melakukan pemantauan kepada anak } \\
\text { didik }\end{array}$ \\
\hline
\end{tabular}




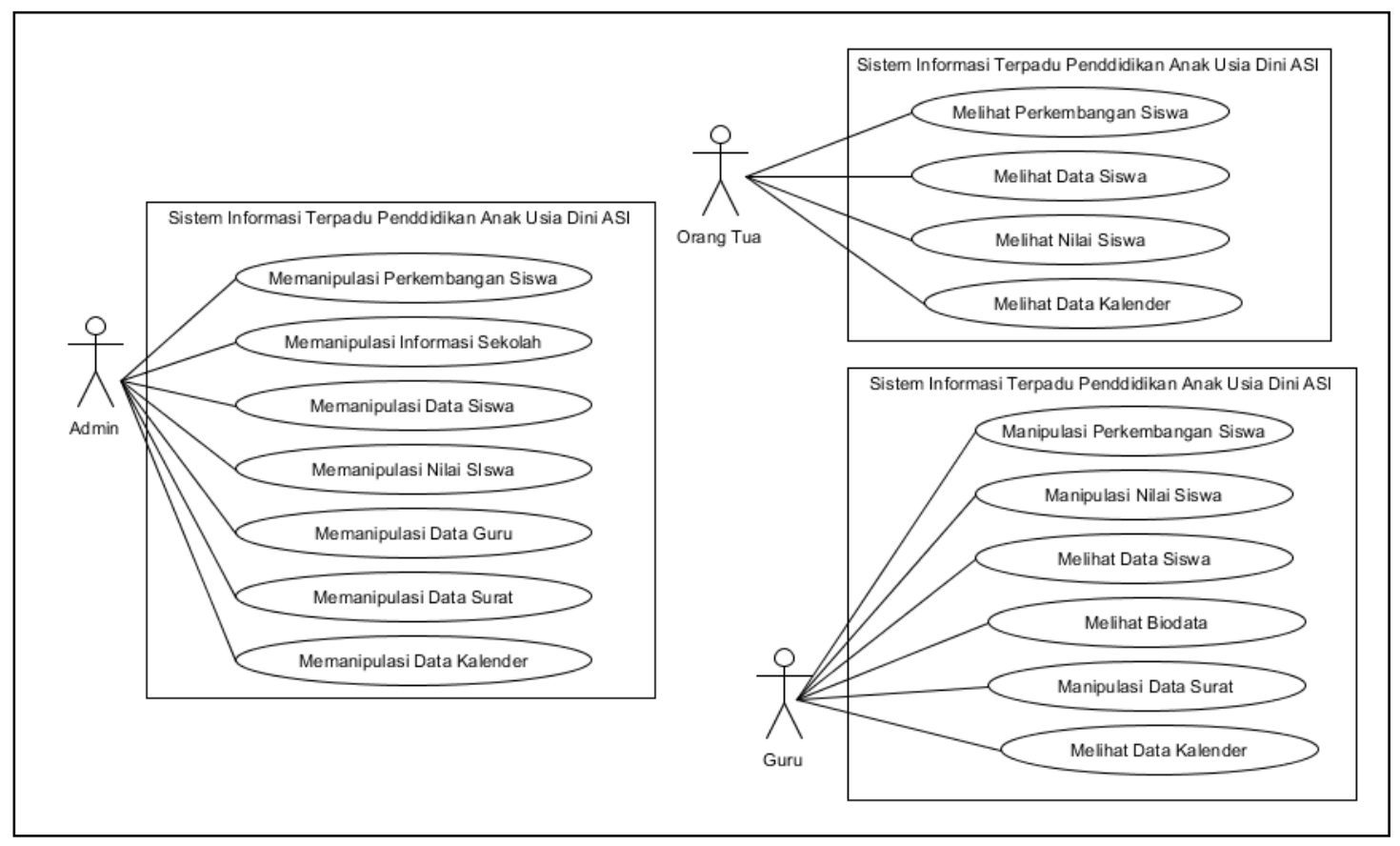

Gambar 2. Use Case Diagram Sistem Informasi Terpadu ASI

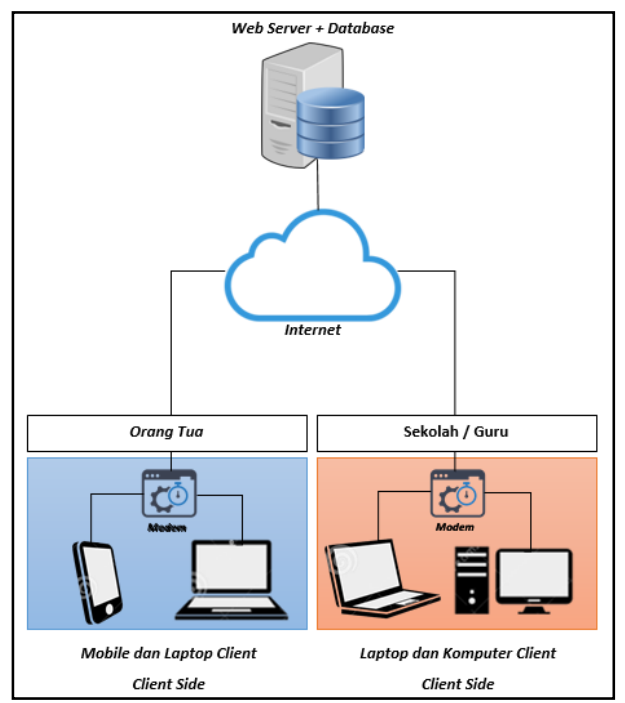

Gambar 3. Arsitektur Komputer Sistem Informasi Terpadu ASI

UML merupakan Bahasa standar industri yang digunakan untuk merancang, dan mendokumentasikan perangkat lunak yang akan dikembangkan. Gambar 2 menunjukan Use Case Diagram dari perangkat lunak. Definisi aktor merupakan penjelasan dari apa yang dilakukan oleh aktor-aktor yang terlibat dalam perangkat lunak yang dirancang. Adapun deskripsi dari aktor-aktor yang terlibat dalam Perangkat Lunak Sistem Informasi Terpadu dipaparkan pada Tabel 2.

C) Perancangan Perangkat Lunak Perangkat lunak Sistem Informasi Terpadu Pendidikan Anak Usia Dini ASI Singaraja dirancang menggunakan 18 tabel yang berfungsi menyimpan data sesuai dengan peruntukannya pada proses-proses tertentu. Selain perancangan tabel juga dirancang hubungan basis data yaitu dengan ERD. Entity Relationship Diagram (ERD) merupakan suatu cara untuk menjelaskan kepada para pemakai tentang hubungan antar data dalam basis data secara logic dengan persepsi bahwa real world terdiri dari objek-objek dasar yang saling berhubungan dengan 
cara menvisualisasikan ke dalam bentuk simbol-simbol grafis [10]. Arsitektur perangkat lunak Sistem Informasi Terpadu Pendididkan Anak Usia Dini Aura Sukma Insani menggunakan arsitektur client server yang mana arsitektur client server merupakan arsitektur yang sudah banyak digunakan dalam berbagai pengembangan sistem informasi. Pada arsitektur ini server akan memberikan informasi kepada client sesuai dengan kebutuhan yang dilakukan pada client. Adapun gambar Arsitektur Komputer dijelaskan apda gambar 3. Pada bagain server menggunakan Laravel sebagai framework untuk mengembangkan sistem. Laravel sangat menarik, sehingga apapun yang ditulis dalam laravel dapat dikemas dalam sebuah kemasan [7]. Pada sistem client digunakan sistem operasi android sebagai sistem operasi yang digunakan. Sistem Operasi Android memiliki 2 jalur disribusi. Jalur distribusi pertama oleh Google atau Google Mail Services (GMS). Jalur kedua adalah menggunakan pola distribusi secara bebas tanpa dukungan langsung dari pihak Google, yang dikenal sebagai Open Handset Distribution (OHD) [6]. Android merupakan salah satu sistem operasi telepon pintar yang populer digunakan di dunia. Dilansir data dari International Data Corporation (IDC) menunjukkan bahwa Android memiliki $82,8 \%$ pangsa pasar di seluruh dunia, sementara iOS hanya memperoleh $13,9 \%$ [9].

\section{HASIL DAN PEMBAHASAN}

Berdasarkan implementasi dari hasil analisis dan perancangan perangkat lunak Sistem Informasi Terpadu Pendidikan Anak Usia Dini Studi Kasus Pendidikan Anak Usia Dini ASI (Aura Sukma Insani) Singaraja terdapat beberapa hasil implementasi yaitu (A) Implementasi Perangkat Lunak, pada implementasi perangkat lunak dibagi menjadi dua yaitu (1) Lingkungan Implementasi Perangkat Lunak dalam lingkungan perangkat lunak dibahas (a) Spesifikasi Perangkat Keras Sistem Informasi Terpadu Pendidikan Anak Usia Dini ASI Singaraja ini dikembangkan pada lingkungan perangkat keras komputer mobile (laptop) yang memiliki spesifikasi sebagai berikut. (1) Processor Intel core i3 2.20GHz (2) RAM GB (3) Kartu Grafis Nvidia GeForce Cuda 520M 1 GB (4) Monitor 14 inch dengan resolusi 1366 x 786 px. kemudian pada (b) Spesifikasi Sistem Informasi Terpadu Pendidikan Anak Usia Dini ASI Singaraja dikembangkan pada lingkungan perangkat lunak sebagai berikut. (1) Sistem Operasi Microsoft Windows 10 Pro 64-bit. (2) Bahasa pemrograman Java, XML, PHP, HTML5, CSS3, JavaScript dan MySQL. (3) Database server package yang digunakan adalah XAMPP versi 3.3.2. (4) Google Chrome browser. (5) Web framework Laravel 5.3 (6) Text editor Sublime Text dan Notepad++ dan Android Studio. (2) Implementasi Antarmuka Perangkat Lunak Pada gambar 4 merupakan tampilan antarmuka home atau beranda yang merupakan halaman yang ditampil saat pertama kali user mengakses sistem informasi terpadu. Kemudian pada gambar 5 merupakan halaman login yang digunanakan untuk melakukan login user sesuai dengan hak akses yang telah diberikan. Gambar 6 menujukan halaman dashboard untuk admin, admin merupakan super user yang dapat melakukan semua fungsi dalam sistem informasi terpadu Dilanjutkan gambar 7 yaitu halaman dashboard untuk orang tua siswa. User orang tua siswa hanya memiliki beberapa fitur yaitu mengubah data pribadi dan melihat data nilai serta data event.

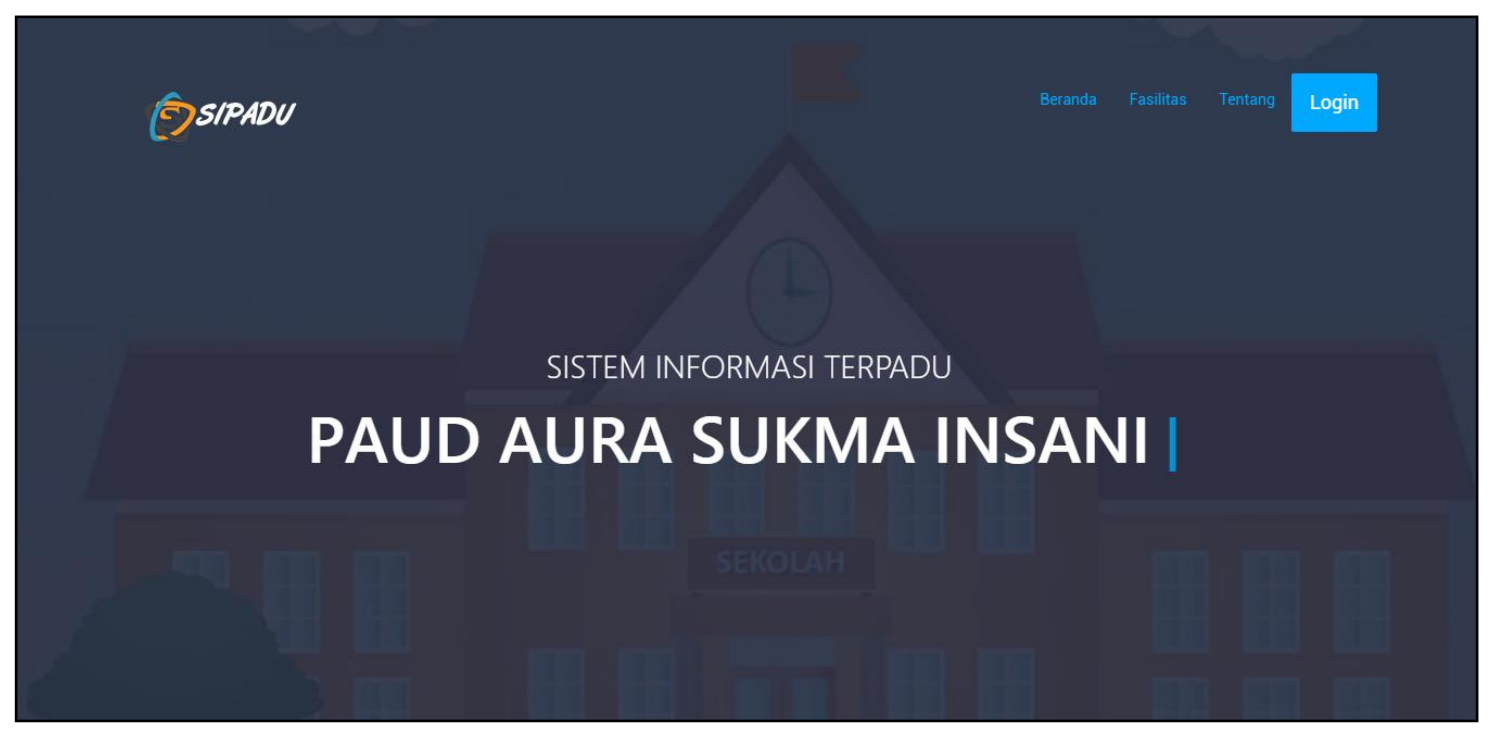

Gambar 4. Halaman Beranda Sistem Informasi Terpadu ASI 


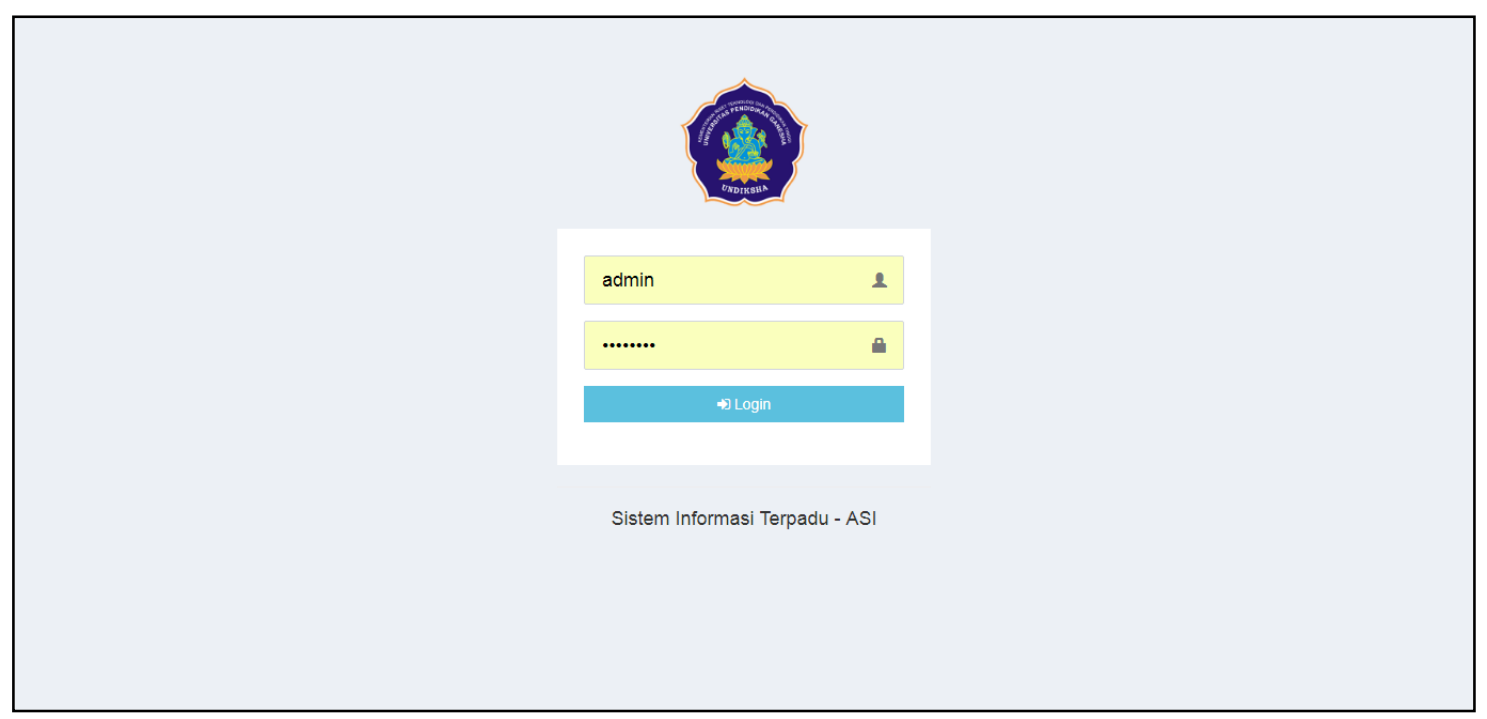

Gambar 5. Halaman Login Sistem Informasi Terpadu ASI

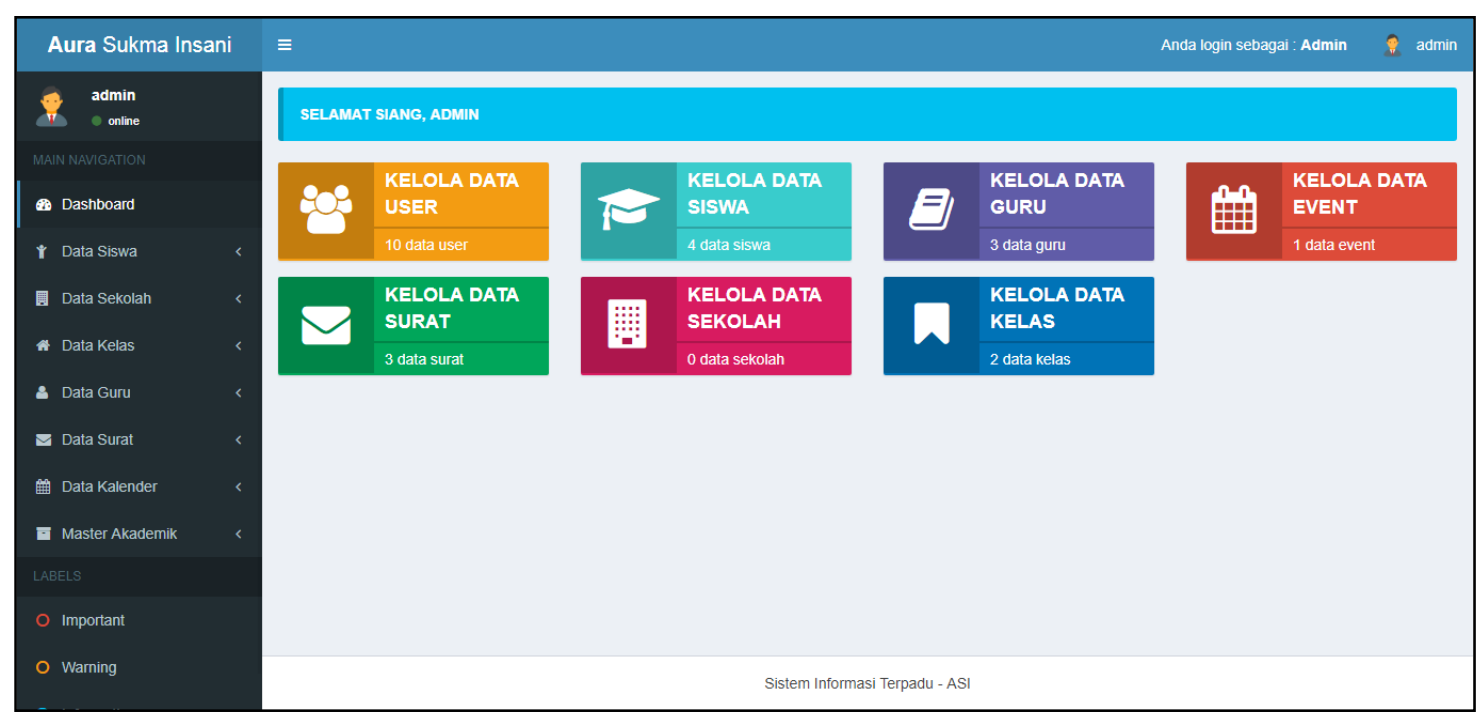

Gambar 6. Halaman Control Panel untuk Admin Sistem Informasi Terpadu ASI

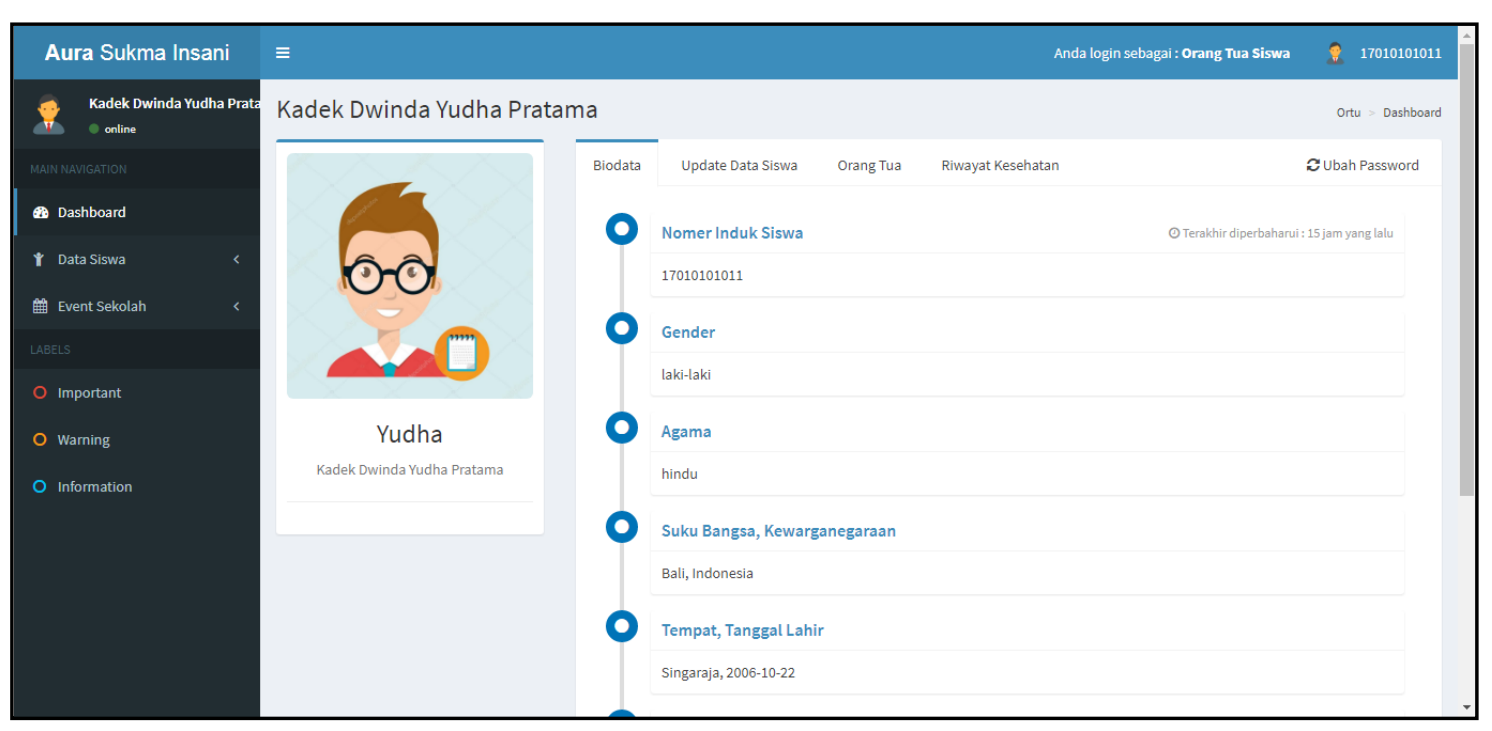




\section{Gambar 7. Halaman Control Panel untuk Orang Tua Sistem Informasi Terpadu ASI}

(B) Pengujian Perangkat Lunak, dalam pengujian perangkat lunak dibagi menjadi empat tahapan yang pertama adalah (a) Tujuan pegujian perangkat lunak dalam tujuan perangkat lunak (1) Whitebox testing, dilakukan dengan memeriksa logika kode program yang telah dibuat dengan menguji beberapa modul dengan hasil output yang dihasilkan. (2), Blackbox testing juga disebut functional testing, sebuah teknik pengujian fungsional yang merancang testcase berdasarkan informasi dari spesifikasi [8]. (3) Pengujian Lapangan, dilakukan untuk menguji respon pengguna terhadap sistem, dalam hal ini pegawai dan guru PAUD ASI sebagai pengguna sistem informasi. (4) Pengujian Kelayakan, bertujuan untuk mengetahui apakah sistem layak untuk di implementasikan. Kemudian dilanjutkan dengan

(b) Tata ancang dan teknik pengujian perangkat lunak yaitu (1) Whitebox testing, meliputi pengujian kesesuaian implementasi proses dan algoritma yang dibutuhkan untuk berbagai proses membuat, mengubah, dan menghapus data masukan dari pengguna. (2) Blackbox testing, meliputi pengujian seluruh fungsi dan kesesuain inputan, proses dan keluaran yang dihasilkan sistem yang telah dijalanan oleh pengguna, sehingga dapat dipantau keberhasilan proses tersebut. (3) Pengujian Lapangan, pengujian ini dilakukan untuk menguji respon pengguna terhadap sistem yang telah berjalan. (4) Pengujian Kelayakan, meliputi pengujian kebenaran fungsi-fungsi yang telah berjalan pada sistem sebagai pendukung dalam pembuatan keputusan dalam penentuan prioritas perbaikan jalan. Tahap yang ketiga adalah (c) Pelaksanaa pengujian perangkat lunak ,adapun pelaksanaan pegujian perangkat lunak sebagai berikut (1) Pengujian kotak putih dilaksanakan pada 1 Juli 2018 dilakukan oleh peneliti. pengujian yang dilakukan sesuai tata ancang yang sudah dipersiapkan. (2) Pengujia kotak hitam dilaksanakan pada tanggal 16 Juli 2018 oleh dua orang penguji, yaitu 1). Made Widiatmika, dan 2). Pradnya Utami. Pada tanggal 17 Juli 2018 oleh tiga orang penguji yaitu guru-guru yang mengajar di Pendidikan Anak Usia Dini ASI. (3) Pengujian respon pengguna dilakukan pada tanggal 17 Juli 2018 oleh guru-guru yang mengajar di Pendidikan Anak Usia Dini ASI Singaraja.

Tabel 3. Hasil Respon Pengguna Sistem Informasi Terpadu ASI

Responden Jawaban Responden untuk Item Nomor

Jumlah Rata-rata

\begin{tabular}{ccccccccccccc} 
& 1 & 2 & 3 & 4 & $5(-$ & 6 & $7(-$ & 8 & 9 & 10 & & \\
\hline R1 & $(+)$ & $(-)$ & $(+)$ & $(+)$ & ) & $(+)$ & ) & $(+)$ & $(+)$ & $(+)$ & & \\
R2 & 4 & 3 & 4 & 5 & 5 & 4 & 4 & 4 & 4 & 5 & 43 & 86 \\
R3 & 5 & 4 & 5 & 4 & 4 & 5 & 5 & 4 & 5 & 4 & 42 & 84 \\
\hline
\end{tabular}

$$
\begin{aligned}
& \text { Presentase }=\frac{\text { jumlah presentase seluruh subyek }}{\text { banyak subyek }} \times 100 \% . \\
& =\frac{254}{3} \times 100 \%=84,67 \%
\end{aligned}
$$

Berdasarkan persentase keseluruhan subyek maka diperoleh hasil respon adalah Baik, yaitu 84,67 \%. (4) Pengujian ini dilaksanakan pada tanggal 17 Juli 2018 oleh guru-guru yang mengajar di Lembaga Pendidikan Anak Usia Dini ASI. Adapun hasil pengujian yang telah dilaksanakan bahwa data yang diinputkan oleh user sesuai dengan data yang ditampilkan oleh sistem. Maka sistem informasi terpadu LAYAK digunakan di Pendidikan Anak Usia Dini ASI (Aura Sukma Insani).

Tahap yang terakhir adalah (d) Evaluasi hasil pengujian perangkat lunak, Pelaksanaan pengujian perangkat lunak berlangsung dengan baik dan lancar. Berdasarkan hasil pengujian whitebox testing (pengujian struktural) diperoleh bahwa implementasi algortima telah berhasil sehingga mendapatkan hasil yang sesuai. Kemudian pengujian blackbox testing (pengujian fungsionalitas) diperoleh bahwa semua proses yang dilakukan oleh user mampu berjalan dengan baik dan menghasilkan inputan yang sesuai dengan spesifikasi. Selanjutnya berdasarkan pengujian respon pengguna atau pengujian lapangan diproleh hasil baik atau sebesar $84,67 \%$ yang mana menyatakan bahwa sistem telah memenuhi kebutuhan dari user. Pada pengujian kelayakan sistem hasil yang diperoleh bahwa Sistem Informasi Terpadu Pendidikan Anak Usia Dini Studi Kasus Pendidikan Anak 
Usia Dini ASI Singaraja LAYAK diterapkan sebagai sistem administrasi untuk menunjang efektfitas dan efisiensi akademik di PAUD ASI.

Pendidikan memiliki banyak peranan penting dalam perkembangan hidup manusia. Salah satu peran penting pendidikan adalah menciptakan masyarakat yang cerdas, terbuka dan demokratis. Pendidikan sudah merupakan menjadi kebutuhan bagi setiap individu. Oleh karena itu pembaharuan pendidikan harus dilakukan untuk meningkatkan kualitas pendidikan [1]. Pendidikan adalah usaha sadar dan terencana untuk mewujudkan suasana belajar dan proses pembelajaran agar peserta didik secara aktif mengembangkan potensi dirinya untuk memiliki kekuatan spiritual keagamaan, pengendalian diri, kepribadian, kecerdasan, ahlak mulia, serta keterampilan yang diperlukan dirinya, masyarakat, bangsa dan negara.

Mengembangkan potensi diri seorang anak merupakan salah satu tugas dari Lembaga Pendidikan terutama pada masa anak mulai mengenal lingkungan yaitu pada masa usia dini. Lembaga Pendidikan Anak Usia Dini mengambil peranan pentig dalam mengembangkan potensi anak mulai dari karakteristik anak itu sendiri. Dalam standard proses akademik pada Lembaga Pendidikan Anak Usia Dini sangat penting dilakukan pembaharuan agar dapat mengikuti perkembangan Pendidikan. Merujuk pada pembaharuan tersebut maka peneliti melakukan wawancara terhadap salah satu Lembaga Pendidikan Anak Usia Dini yaitu PAUD ASI terkait dengan standard proses akademik, ditemukan beberapa masalah yaitu salah satunya adalah masih digunakan metode konvensioanl dalam melakukan penilaian terhadap siswa kemudian informasi terkait anak ditak dapat diakses oleh orang tua siswa secara realtime.

Berdasarkan permasalahan tersebut peneliti melakukan kajian terhadap penelitian terkait dengan masalah yang ditemukan. Pengembangan teknologi merupakan salah satu cara untuk mengatasi masalah tersebut, pengembangan teknologi yang dimaksud adalah mengembangkan perangkat lunak sistem informasi terpadu. Dari hasil temuan kajian tersbut peneliti termotivasi untuk mengembangkan sistem informasi yang serupa melalui penelitian dengan judul "Pengembangan Sistem Informasi Terpadu Pendidikan Anak Usia Dini Studi Kasus Pendidikan Anak Usia Dini ASI (Aura Sukma Insani) Singaraja".

Metode pengembangan perangkat lunak Pengembangan Sistem Informasi Terpadu Pendidikan Anak Usia Dini Studi Kasus Pendidikan Anak Usia Dini ASI (Aura Sukma Insani) Singaraja ini mengacu pada metode SDLC (Software Development Life Cycle). Model yang digunakan pada metode SDLC merupakan model waterfall dan permodelan menggunakan diagram UML (Unified Modelling Languange). Adapun tahap yang dilakukan dalam penelitian sesuai dengan model waterfall adalah tahap analisis, perancangan, implementasi dan pengujian. Tahap pertama dalam model waterfall adalah analisis kebutuhan (requirements analysis and definition) perangkat lunak. Analisis kebutuhan dilakukan untuk mengetahui kebutuhan dari proses pengembangan perangkat lunak. Selanjutnya adalah tahap perancangan (System dan Software Design) tahap perancangan perangkat lunak dibuat berdasarkan pada tahp analisis yang telah dilakukan sebelumnya. Hasil rancangan perangkat lunak yang dibuat akan menjadi dasar dalam melakukan implementasi perangkat lunak.

Sistem Informasi Terpadu Pendidikan Anak Usia Dini Studi Kasus Pendidikan Anak Usia Dini ASI (Aura Sukma Insani) Singaraja pada tahap implementasi dikembangkan dengan menggunakan Web Framework Laravel dan Android Studio. Pengembangan sistem informasi ini menggunakan arsitektur komputer client-server, web base pada sisi server dan mobile aplikasi pada sisi client. Pada web base beberapa fungsi yang diimplementasikan adalah fungsi pengelolaan data seperti data siswa, data nilai siswa, data guru, data sekolah, data surat, dan data kalender. Sedangkan pada mobile aplikasi fungsi yang dimplementasikan adalah fungsi untuk menerima pesan dari sisi server, pesan yang diterima dari sisi server berupa data text. Pengiriman pesan secara real time menggunakan memanfaatkan fitur Cloud Messaging dari Google Firebase.

Sistem Informasi Terpadu Pendidikan Anak Usia Dini Studi Kasus Pendidikan Anak Usia Dini ASI (Aura Sukma Insani) Singaraja telah berhasil dikembangkan dan telah berhasil di melalui tahap pengujian. Pengujian respon pengguna menunjukan nilai sebesar $84,67 \%$ yang menyatakan bahwa semua kebutuhan dari pengguna telah terpenuhi. Pada pengujian kelayakan sistem informasi terpadu dinyatakan layak karena semua data yang diinputkan oleh user sesuai dengan yang dihasilkan oleh sistem

Berdasarkan hasil dari beberapa pengujian yang dilakukan dapat dinyatakan bahwa tujuan penelitian sudah tercapai. Hal tersebut dilihat dari hasil pengujian struktural (whitebox testing), pengujian fungsional (blackbox testing), pengujian lapangan (respon pengguna), pengujian kelayakan sistem yang mendapatkan hasil yang baik. Dari hasil yang sudah didapatkan pengembangan sistem informasi terpadu tidak terlepas dari beberapa kekurangan dari sistem informasi terpadu, seperti dari sisi mobile dapat dikembangkan pada sistem operasi android. Penambahan fitur chat real-time yang 
memudahkan sesama pengguna untuk dapat saling berinteraksi karena pada sistem ini hanya berjalan satu arah yaitu informasi dari sistem pada web dikirim ke aplikasi mobile.

\section{SIMPULAN DAN SARAN}

Berdasarkan paparan hasil analisis, perancangan, implementasi, dan pengujian Sistem Informasi Terpadu Pendidikan Anak Usia Dini Studi Kasus Pendidikan Anak Usia Dini ASI (Aura Sukma Insani) Singaraja yang telah dilaksanakan pada penelitian ini maka dapat diambil kesimpulan sebagai berikut. Pengembangan Sistem Informasi Terpadu berhasil mengatasi masalah yang terjadi pada Lembaga Pendidikan Anak Usia Dini Aura Sukma Insani. Dikembangkan dengan Metode SDLC dengan model Waterfall pengembangan dari sistem ini berjalan sesuai rule model yang digunakan yang mana setiap tahapannya dilakukan evaluasi untuk mendapatkan hasil yang maksimal. Sistem Informasi Terpadu dengan dasar menggunakan web sebagai plaform utama yang memudahkan pengguna untuk mengakses sistem ini. Platform web dalam permasalahan administratif sangat membantu untuk meningkatkan efisiensi waktu dalam segala pekerjaan. Selain dikembangkan dalam platform web sistem juga dikembangkan dalam plaform android, android menjadi salah satu pilihan dikarenakan pengguna android di Indonesia lebih banyak dibandingkan pengguna OS lain. Pada sistem di Android digunakan untuk orang tua siswa sehingga dapat mengakses informasi terkait anaknya secara langsung. Hasil dari beberpa pengujian yang dilakukan menyatakan hasil positif terkait pengembangan sistem informasi terpadu.

Terdapat beberapa saran untuk peneliti yang melakukan penelitian selanjutnya yaitu sebagai berikut. (1) Sistem informasi yang dikembangkan agar ditambahkan fitur chat real time untuk membantu komunikasi lebih baik yaitu komunikasi dua arah antara sekolah dan orang tua. (2) Aplikasi mobile dibutuhkan pengembangan lebih lanjut untuk sistem operasi yang digunakan sebagai base sistem selain sistem operasi android, seperti IOS. Untuk menambah jumlah pengguna dari device yang dapat menggunakan aplikasi mobile dari sistem informasi terpadu.

\section{DAFTAR PUSTAKA}

[1] Mujtaba, I. (2015). Standarisasi Alan Usia Dini. Malang: FIP UMNJ.

[2] Kemendikbud. (2014). Buku Panduan Pendidik Kurikulum 2013 Paud Anak Usia 5-6 tahun. Jakarta: Kementrian Pendidikan dan Kebudayaan.

[3] Sommerville, I. (2011). Software Engineering (Rekayasa Perangkat Lunak). Jakarta: Erlangga.

[4] Thomas, P. (2013). Peran Sistem Informasi Manajemen "Management Information System" Dalam Menigkatkan Kualitas Pendidikan Kejuruan. Seminar International, ISSN 1907-2066, Peran LPTK Dalam Pengembangan Pendidikan Vokasi di Indonesia APTEKINDO, 433.

[5] O'brien, J. A. (2005). Pengantar Sistem Informasi Perspektif Bisnis dan Manajerial. Jakarta: Salemba Empat.

[6] Istiyanto, J. E. (2013). Pemrograman Smartphone Menggunakan SDK ANdroid dan Hacking Android. Yogyakarta: Graha IImu.

[7] McCool, S. (2012). Laravel Starter. Birmingham: Packt Publishing.

[8] Nidhra, Srinivas, \& Dondeti, J. (2012). Black box and White box Testing Techniques - A Literature Review. Internasional Journal of Embedded System and Applications (IJESA) Vol.2, No.2.

[9] IDC. (2016, August 10). International Data Corporation. Retrieved from http://www.idc.com/home.jsp: http://www.idc.com/prodserv/smartphone-os-market-share.jsp

[10] Dolly, I. (2004). Perancangan Sistem Informasi II. Bandung: Universitas Komputer Indonesia

[11] KBBI. (2016, August 10). Kamus Besar Bahasa Indonesia. Retrieved from http://kbbi.web.id/: http://kbbi.web.id/telepon

[12] Gumilar, S., Munir, M., \& Susrama, I. (2012). Sistem Informasi Akademik Pada Paud Nur Insani Surabaya Berbasis Web. 1-2. 